\title{
Trade Openness and Economic Growth: A Vision Based on Export Growth for MENA Countries
}

\author{
Naoufel Mahfoudh", Fatima Alhamshary, Bashair Al Eisa \\ Administrative and Financial Sciences Department, Community College, Imam Abdulrahman Bin Faisal University, Saudi Arabia \\ *Corresponding author: nomahfoudh@iau.edu.sa
}

Received August 12, 2018; Revised September 15, 2018; Accepted September 28, 2018

\begin{abstract}
This paper examines the effect of trade openness on economic growth based on export growth as a key variable for the MENA region. We use different methods of estimating the coefficients relative to each variable on a panel of MENA countries over the period 1990-2014. The conclusion is that openness to international trade is generally beneficial for the countries of the MENA region. The effect of openness is also important and that is going through the growth of exports. According to the results, for these countries the diversification of exports is very important insofar as, in addition to its significant effect on economic growth, it is a major asset in supporting exports. Non-oil-exporting MENA countries are called upon to rely more on diversification to support and strengthen the pace of exports, which is a very important factor in taking advantage of the opening of trade. Strengthen the role of institutions and improve the attractiveness of high-tech foreign direct investments. Oil-exporting countries are also called upon to diversify their economies and boost the internal drivers of economic growth.
\end{abstract}

Keywords: trade openness, economic growth, export growth, Middle East and North Africa Countries

Cite This Article: Naoufel Mahfoudh, Fatima Alhamshary, and Bashair Al Eisa, "Trade Openness and Economic Growth: A Vision Based on Export Growth for MENA Countries." International Journal of Econometrics and Financial Management, vol. 6, no. 2 (2018): 36-44. doi: 10.12691/ijefm-6-2-2.

\section{Introduction}

The wave of liberalism that has swept the world since the 1980s has focused on a fundamental issue, namely the effect of liberalization and trade openness on economic growth.

In this context, where the determinants of economic growth remain an important issue in economic research, the literature has identified several growth factors such as policies, institutions and geography (Lee and Kim 2009) [1]. Among these political factors are often the policies of economic integration and openness, which are adopted by the Washington consensus (Williamson 1990, 1994, 1996). However, experiences show that none of the traditional factors can influence economic performance unless a stable and reliable institutional environment is in place to support the economy. Indeed, the importance of institutions and political choices must be accompanied by resistance to the prevalence of corruption, the failure of property rights and the weakness of the law (Rodrik, Subramanian and Trebbi (2004) [2]).

This denunciation of the importance of institutions and political choices (integration into the world economy and openness) gave rise to a renewal of the research current, which focuses on the phenomenon of "growth spurts" in the short term which is produced in many countries of the South. Jones and Olken (2005) [3], Haussman, Pritchett and Rodrik (2005) [4] and Rodrik (2006) [5] have noted that many developing countries succeed in posting growth spurts for a period of time (usually less than a decade) Growth over a longer period. These studies underscore the importance of sustaining growth rather than just initiating it in the short term. In this context, it is important to highlight the related growth trap phenomenon for middleincome countries. In other words, the problem of slowing growth in middle-income countries, as highlighted by Eichengreen, Park and Shin (2012) [6], Lee (2013) [7] and the World Bank (2010) [8]. Despite the efforts made by these countries in their process of becoming more integrated with the world economy and opening up, these countries have faced a challenge to maintain growth over the long term. Although the benefits of economic integration and openness have been recognized in the broad literature, the real effects of openness and the variables that would represent the best international integration are still under debate. Several researchers consider that trade openness is not robust as a factor of economic growth (Rodriguez and Rodrik (2001) [9], Yanikkaya (2003) [10], Vamvakidis (2002) [11], Lee and Kim (2009) [1]). Openness is only a catalyst for long-term growth, since the rate effects or dynamic gains identified, in particular, by endogenous growth theories require preconditions. This leads to the adoption of the idea of a progressive opening.

The logic of looking for the conditions to take advantage of economic integration and the openness to sustained economic growth has motivated this study to review the importance of international economic integration based on a revision of the economic variables, Opening 
trade. Indeed, export diversification, foreign direct investment (FDI), openness, and dummy variables related to the abolition of tariff and non-tariff barriers, have shown these limits to the extent 'Identify the effect without providing leads to carry out actions to support growth.

This study suggests export growth as a variable not only to identify the effect but also to provide avenues to support economic growth. In fact, considering exports as an important factor of economic growth is not new. In particular, the good performance achieved by many emerging countries was characterized by the success of increasing the rate of growth of exports (Led-ExportGrowth strategy).

However, the emerging literature argues that it is not enough to start and increase growth for a short period of time, but it is necessary to support exports by what is essential for economic growth. As a result, several studies on sustaining economic growth through the maintenance of a favorable export pace are increasingly focused on the issue of export survival and address various variables such as comparative advantage, Export competitiveness, export diversification, export learning (Brenton, Saborowski and Uexkull (2010) [12], Nitsch (2009) [13], Fugazza and Molina (2009) [14], Cadot, Carrere and Strauss-Kahn (2011, 2013) $[15,16])$. These studies assume that export growth (supporting exports) is one of the fundamentals of economic growth and is therefore seen as a major challenge for emerging countries. Indeed, export is the main source of foreign exchange that allows the importation of machinery and intermediate goods necessary for investment.

In this paper, we will try through this work to examine the effect of trade openness on economic growth based on export growth as a key variable for the MENA region. Based on the theoretical and empirical literature, we will also compare the effect of openness through export growth and other variables such as openness, diversification and FDI of course, not to mention the other determining variables of economic growth. This is done through different methods of estimating the coefficients for each of the variables on a panel of MENA countries over the period 1990-2014.

This paper will be organized as follows, section 2 will be devoted to reviewing the theoretical and empirical literature to explain the mechanisms of transmission of the effects of trade openness on economic growth. Section 3 will cover the presentation of the model and the empirical method. Results and recommendations will be discussed in Section 4.

\section{Review of the Literature}

\subsection{Overview of the Main Theoretical Studies}

Several papers have dealt with the subject of growth in open economies with a common point in explaining how this openness to trade affects economic growth. The fundamental question has been about the mechanisms of transmission and the preconditions for openness to be beneficial for growth and well-being. At that time several approaches to the international economy stipulate that the gains in international trade are classified into two types, the static gains presented by the traditional theories of international trade and the dynamic gains highlighted by endogenous growth theories. Indeed, the static gains are in terms of welfare gain due to the effects of trade liberalization on the economic structure (specialization, allocation of resources ...). The dynamic gains are in terms of growth bonuses due to the effects of trade liberalization on growth engines, associated with technical progress, human capital and the expansion of the stock of knowledge.

In this context, international economics is one of the most important fields of application of endogenous growth models, thus offering a new vision of the international specialization of comparative advantages and exchange flows.

The analysis of the impact of economic integration on the structure of trade has been profoundly renewed on the basis of international trade theories (Helpman and Krugman (1985) [17]) and the new geographical economy (Krugman (1991) [18]). These models usually start from the questioning of traditional theories with the Ricardian model and the Hecksher Ohlin Samuelson (HOS) model.

The reality of international trade is characterized by the existence of tariff and non-tariff barriers and various transaction costs with different legal systems and commercial practices. Thus, distance remains the major handicap to trade flows. Fontagné, Mayer and Zignano (2005) [19] found that in the European Union, a country carries out trade 12 times more with itself than with another comparable partner in the union. Tinbergen (1962) [20] revised Newton's law of universal attraction to analyze trade flows between countries according to the size of trading partners and the distance between them. Econometric studies based on a gravitational model show that remoteness affects international trade negatively. Disdier and Head (2008) [21] concluded that doubling the distance would lead to a halving of trade. The following box presents the logic of the gravitational model.

Developments in the economic literature, the challenge of which was to integrate the respective contributions of the theory of international trade and theories of endogenous growth. These contributions focus on highlighting increasing returns to scale and imperfect competition to explain both contemporary upheavals in the structure of trade (intra-industry trade) and the new engine of innovation in growth. A fundamental relationship links growth to the long-term effects of technical progress and innovation. In an open economy, the effects of technical progress are amplified and spread through technology transfer. By acting on the factor of capital accumulation in a country, they are likely to change the dynamics of its growth. What remains to be seen is the phenomenon of growth, technological progress or international openness that is the most responsible for increasing inequalities.

The endogenous growth models that develop in the 1990s show that trade favors growth through the exchange of intermediate goods (Young (1991) [22], Grossman and Helpman (1991) [23], Revera-Batiz and Romer (1991) [24]). This openness makes it possible to increase the stock of knowledge of the co-trader countries by increasing the number of varieties of intermediate goods available, thus generating productivity and growth gains (Revera Batiz and Romer (1991)). In the same context, the 
accumulation of human capital plays an essential role in the growth process (Mankiw, Romer and Weil (1992) [25]).

Inspired by the increased growth model of Solow (1956) [26], the Mankiw, Romer and Weil Model establishes a relationship between an endogenous variable that is growth measured by the average annual growth rate of per capita income, and exogenous variables that are, initial income, saving rate, population growth rate and human capital.

Effect of broadening the size of the market and increasing the number of varieties of intermediate goods: trade openness leads to an enlarged market size and thus allows member countries to access a greater number of intermediate goods varieties. Thomas F. Rutherford and David Tarr (1998) [27] have developed a dynamic model that examines the effect of openness on growth based on these two channels. According to them, a reduction in tariffs results in a reduction in the selling price of imported intermediate goods. This allows the entry of several varieties of capital goods, resulting in improved production and growth.

Effect of learning and specialization: similarly for this channel, several endogenous growth models can provide a framework for theoretical analysis. Grossman and Helpman (1991) [23], combined Hicksher Ohlin's theory with the shumpterian growth model to give rise to an endogenous formulation of comparative advantage. Young (1991) [22] developed a bounded "leaning by doing" based on the Ricardian international trade model, in which exchange is derived from differential technologies rather than factor endowments. According to Young, exchange leads a developed country to specialize in the production of the good where it has a higher potential for productivity enhancement due to learning effects, whereas a less developed country needs to specialize In the property for which it has a potential for lower productivity improvement.

Under these conditions, openness can cause a decline in the rate of growth for the least developed country and accelerate it for the developed country, although the allocative effects allow an increase in the level of utility of the consumers in each country.

Se-Jik Kim and Young Jin Kim (1999) [28] studied the different mechanisms of the international trade-human capital-economic growth relationship. Based on the example of Asian countries that have achieved high growth as a result of the liberalization of their economies, they suggest that greater openness to exchange leads to more knowledge and technical progress.

These factors have a positive impact on growth through their effects on human capital productivity and growth, provided that the country in question is prepared for openness by increasing the level of general education.

Technological diffusion, knowledge stock expansion and economic growth: International trade allows outwardoriented countries to benefit from a technological diffusion that results from the exchange of goods and ideas. Revera Batiz and Romer (1991) [24], have developed an endogenous growth model that addresses the effect of economic integration on growth by focusing on the effect of two factors (technological diffusion and knowledge stock expansion) on Innovation, which they believe is the main driver of economic growth.
Indeed, according to Revera Batiz and Romer (1991), the exchange of goods and the flow of technological knowledge enable integrated countries firstly to increase market size and improve their innovative capacities.

\subsection{Presentation of Key Empirical Studies}

As already mentioned, the effects of trade openness on economic growth is an issue that has attracted the interest of economic researchers. Many studies have dealt with this subject. The difference of these works lies in the choice of the empirical methods used and especially in the variables chosen to estimate the effect of the opening. Since our approach is based on the importance of export growth as an openness variable, we will try to compare it with other variables used previously, namely the share of trade or the rate of Openness, Foreign Direct Investments (FDI), export diversification, the following discussion will focus on the presentation of the hypothetical links of these variables and on the work using these variables.

\subsubsection{Trade Openness}

Trade openness often measured by the weight of trade (import and export) in GDP, is a typical variable representing international integration. Using a wide range of openness measures, including subjective indicators, Sachs and Warner (1995) [29] have demonstrated a positive and robust relationship between openness and economic growth. A positive and statistically significant correlation of openness with growth and investment was demonstrated by Vamvakidis (1999) [30] and Harrison (1996) [31], using the estimation of panel data. Yanikkaya (2003) [10] explained that openness and growth have a positive and significant association. On the other hand, others believe that trade openness is not robust as a determinant of economic growth. Rodriguez and Rodrik (2001) [9] considered that indicators of openness and measures of tariff and non-tariff barriers are very fragile because these barriers are often highly correlated with sources of institutional mismanagement (corruption, lack of law) That researchers are unable to approximate them. Using transverse regression, Vamvakidis (2002) [11] showed that long-term openness and growth are not always positively correlated.

\subsubsection{Foreign Direct Investments (FDI)}

FDI as a means of financing investment, the main engine of growth, is identified as another variable of economic integration. Outward-oriented governments especially emerging economies are still competing to attract foreign capital with various attractive schemes. Today, FDI is one of the most important sources of foreign financing for these economies. FDI has long been recognized as a major source of technology and knowhow for developing countries. Some research shows that FDI has positive effects on growth, while others indicate that FDI has negative effects. Borensztein, De Gregorio and Lee (1998) [32] found that the effect of FDI on growth depends on technological absorption capacity, technological content and the form of investment. Hsiao and Shen (2003) [33] found that institutional strength and high levels of urbanization are prerequisites for the 
positive effects of FDI on growth in developing countries On the other hand, some studies do not find any relationship between FDI and growth, especially when these FDI come in the form of subcontracting and target intensive sectors for unskilled labor. Adams (2009) [34] analyzed the effect of FDI on economic growth in sub-Saharan Africa using a panel of countries observed over the period 1990-2003. The results indicate that the effect of FDI is positive and significant in the 1990s. Estimation of ordinary least squares and is not significant in the fixed effect estimate. This shows, in a way, that the effect is unstable and depends on the specificities of the countries studied.

\subsubsection{Specialization or Diversification of Exports}

We can measure specialization by the indicator of comparative advantage or by the inverse. The diversification measured by the Herfindhal index, the sum of the squares of the structure, Have two different visions (Agosin, Alvarez and Bravo-Ortega (2011) [35]).

Theoretically, opening up a country to international trade allows us to exploit comparative advantages, to develop sectors where there are economies of scale and better allocation of resources. Each country that opens its borders according to its factor endowments, its initial wealth and its economic policy, will choose a strong specialization according to comparative advantages or develop an intra-branch trade with no specialization. Thus, a country open to trade can: either succeed in positioning itself in a few sectors where the world demand is strong and succeeds in following their evolution, it will achieve a good inter-branch specialization which allows it to better allocate its resources and improve its Performance in economic growth. Either the country fails to specialize and orient itself towards the development of intra-industry trade in capital goods, which will increase the number of intermediate goods that creates productivity gains, a beneficial effect on its growth economic.

Recent studies on detailed trade data show that the export strategy combined with the development of diversified and sophisticated exports and the exploitation of comparative advantages allows for rapid growth. Indeed, Cadot, Carrere and Strauss-Kahn (2011, 2013) [15,16] and Agosin (2008) [36] suggest that export diversification and comparative advantage are key factors in economic growth. Al-Marhubi (2000) [37] provided empirical evidence that export diversification coupled with high investment rates is a key factor in the growth of developing countries. Ferranti, Perry Lederman and Maloney (2002) [38] also found evidence for economic growth oriented towards diversification. A number of business models also imply a link between export diversification and growth. Pineres and Ferrantino (1997) [39] argued that export diversification affects long-term growth as suggested by endogenous growth theory, which emphasizes the role of increasing returns to scale and the effects of dynamic comparative advantages. Felipe, Arnelyn and Utsav (2012) [40] found that upper middleincome countries simultaneously had a diversified, sophisticated export basket capable of transitioning to middle-income countries. Using co-integration and causality tests, Balaguer and Cantavella-Jorda (2004) [41] also found a positive relationship between diversification and growth. Worz (2005) [42] presented further evidence that the specialization of exports in the high-tech sectors argues in favor of growth.

Economic facts and empirical research do not give a clear answer and show that these two strategic choices are not two alternatives. Indeed, diversification is only a low level of specialization and vis versa.

As a result, and taking into account the diverse results with respect to the effect of the export structure, the addition of this dimension to the framework in this research is important for two reasons:

(i) to determine the effect of export diversification or specialization on the growth of the countries of the MENA region that is characterized by a diversification of their trade structure.

(ii) diversification is an important condition for sustaining export growth under the current circumstances of unstable global demand.

\subsubsection{Export Growth}

Economic, theoretical and empirical literature has largely addressed the issue of the importance of exports as an engine of economic growth. In this regard, many researchers have discussed this issue, especially after the success of the East Asian countries in the Led-ExportGrowth strategy and the growth of export-led growth. Recent studies also recognize the importance of exports, but they tend to raise the issue of export sustainability more than the effect of exports on economic growth. Indeed, Brenton, Saborowski and Uexkull (2010) [12] found that the initial size of export flows is one of the important determinants of its survival. Eaton, Eslava, Kugler and Tybout (2008) [43], indicated that the duration of trade relations is important for maintaining export growth. Besedes and Prusa (2007) [44], Brenton and Newfarmer (2007) [45], Helpman, Melitz and Rubinstein (2008) [46] and Nitsch (2009) [13] argued that the duration of trade flow is important for the sustainability of export growth, of economic growth. On the other hand, our interest lies in explaining the value of export growth in the economic growth of MENA countries. In order to generate growth, these countries must invest in capital goods in particular and invest in the production of loadbearing products. This challenge requires MENA countries to export more to increase foreign exchange reserves to finance the import of capital goods from innovative countries or to finance research and development. In other words, export growth promotes economic growth by generating foreign exchange that allows imports of machinery and intermediate goods necessary for investment. The increase in exports is important not only for its power to generate foreign exchange but also for its effects of positive externalities, resulting from increased competition, on productivity. This is talking about export learning. Such a phenomenon has been confirmed by numerous studies in this case (Reinhardt (2000) [47], Jung and Lee (2010) [48]). Moreover, as pointed out by the traditional models of free trade, the outward orientation by the acceleration of exports is a solution to circumvent the constraint on the insufficiency of the size of the market. However, increased competition and fluctuations in international demand following the succession of crises in recent years 
have created a major challenge for developing countries, especially for potential non-exporting MENA countries. oil. Such a challenge lies in supporting export growth.

In summary, the assumption is that export growth is a more robust variable than traditional variables (trade openness, FDI and export diversification) in order to demonstrate the effect of international integration on growth. The increase in the trade-to-GDP ratio cannot support growth, as this ratio may increase due to increased imports, which, even if it generates positive externality effects from capital goods, is accompanied by an aggravation of the trade deficit. The link between FDI and growth often depends on certain initial conditions. The effect of diversification is unclear and remains dependent on the initial conditions and specific characteristics of the country in question.

From the above, growth theorists suggest that the effect of foreign trade on economic growth is manifested through the importation of intermediate goods more specifically capital goods. Indeed, it is the intermediate goods that generate the gains in terms of technological diffusion, improvement of innovative capacities and learning. On the other hand, in the case of the countries studied, it is necessary to seek at least financing to acquire such goods. The solution is therefore in the opening up of trade and the acceleration of exports and the attractiveness of FDI that these countries would have the possibility to leave. Moreover, we also note that the growth gains are conditioned implicitly or explicitly by the resources and the preparation of the country before opening.

Therefore, in order to answer our initial question and to know to what extent MENA countries can draw the growth gains due to trade openness and to what extent the opening effects are attached to the growth of exports as highlighted by Lessons from the literature.

\section{Empirical Study}

The empirical study of this research is to test the effect of trade openness on economic growth for MENA countries by focusing con four openness variables (exports, export growth rate, FDI and export diversification), based on a panel of growth data and its determinants for a sample of countries in the region, we will estimate an equation of economic growth as a function of open variables and other control variables related to the main determinants of growth.

\subsection{Choice and Specification of Variables}

Explanations of growth differentials between countries have drawn several factors for economic growth. Indeed, the theory of convergence that falls within the framework of exogenous growth theories or the Solow gave rise to a fundamental factor in the explanation of the differences in growth, introducing the history of the country and the initial endowments.

The initial effort in economic development and the initial level of income are essential factors in determining today's growth. According to this theory, a country with a low initial income level grow faster than a country with a relatively high level. Since the returns to scale are constant and competition is perfect, marginal productivity is decreasing, according to these two assumptions, marginal productivity vanishes in the long run. In the steady state one can have a convergence of the growth rates of two countries. Thus, among the factors that explain the growth the per capita income level at the beginning of the period.

Solow (1956) [26], Rebelo (1991) [49] and other growth theorists suggest that investment (saving) is the main driver of growth. Barro (1991) [50] and Barro and Sala I Martin (1992) [51] also demonstrated the fundamental role of public investment as a factor for economic growth. Therefore, according to these theoretical suggestions, investment and gross capital formation must be included in the estimation of an equation of growth. Moreover, among the internal drivers of growth, we must not forget the final consumption which, according to the multiplier theory, is a key internal factor in driving economic growth.

Population growth reflects the demographic dynamics of the country and reflects the size of the market. For the level of human capital, measurement problems arise, there is a whole debate about the choice of a variable that reflects this factor. In our case, the number of years in secondary education has been chosen, and this has yielded the best results in other empirical studies.

For the variables of interest which constitute the effect of openness on growth, according to the arguments presented earlier, we have opted for trade weight in relation to GDP, the rate of growth of exports, FDI as a percentage of GDP and the rate of diversification of exports.

\subsection{Presentation of the Model and Data}

The present empirical study consists in estimating a linear equation of GDP growth per capita based on a panel of data from a sample of 13 MENA $^{1}$ countries observed over the period 1990-2014. The equation to be estimated is of the following form:

$$
\begin{aligned}
& g G D P_{-} h_{i t}=c+a_{1} G D P \_i n i t_{i t}+a_{2} S E C_{-} e d u_{i t} \\
&+a_{3} G F C F_{i t}+a_{4} g P O P_{i t}+a_{5} C O N S_{-} f_{i t}+b_{1} F D I \\
&+b_{2} E X P+b_{3} g E X P_{i t}+b_{4} \text { Indivers }_{i t}+u_{i t} .
\end{aligned}
$$

This equation has retained the dependent variable the GDP growth rate per capita g GDP_h (\% annual), and the explanatory variables:

GDP_init, GDP beginning of period (\$ constant 2010) for the year 1990.

SEC_edu, Secondary education, duration (years).

GFCF, Gross fixed capital formation (\% of GDP).

gPOP, Population growth (\% annually).

CONS_f, Final consumption expenditure, (\% of GDP).

FDI, Foreign direct investments, net inflows (\% of GDP).

EXP, Exports of goods and services (\% of GDP).

gEXP, Exports of goods and services (\% annual growth).

Indivers, Index of export diversification (herfindhal index calculated on data by SITC product level 10 chapters).

\footnotetext{
${ }^{1}$ MENA countries that make up our sample are: Bahrain, Saudi Arabia, United Arab Emirates, Kuwait, Qatar, Oman, Egypt, Iran, Jordan, Lebanon, Tunisia, Algeria and Morocco.
} 
In this equation $\mathbf{c}$ is a constant and $\boldsymbol{u}$ is the error term with (i) and (t) index respectively countries and years.

The coefficients $a_{1}$ to $a_{5}$ represent the effect of the variables qualified as controls, that is to say the variables that explain economic growth other than foreign trade. The coefficients $b_{1}$ to $b_{4}$ would represent the effects of relative to the commercial opening variables.

\subsection{Estimation and Results}

As noted we have chosen four variables that represent international economic integration, namely export growth, trade openness, export diversification and FDI. The aim is to investigate the extent to which these variables may represent the effect of openness on economic growth in MENA countries. The robustness of these variables is to be assessed as determinants of economic growth in the countries in the sample.

Moreover, the robustness can be verified in several steps. First, we estimate the growth equation with the control variables and the integration variables. Second, we try different combinations of integration variables. In these iterations and in order to examine the robustness one will change each time the estimation method is "Pooled Least Squares" and "Pooled EGLS" for each regression. Robustness is confirmed only when the variables are significant in the two estimation methods or the month for the PEGLS method.

First, we estimated the model for the total sample using the four variables simultaneously. The results in Table 1 and Table 2 show that for the control variables, the coefficients are not significant except for the case of the growth rate of the population. For the opening variables, the results show a positive and significant effect for FDI as a percentage of GDP, which explains the importance of FDI flows for MENA countries. For trade flows the relationship is statistically significant for the rate of growth of exports and it is not for diversification and the ratio of export to GDP.

\section{Table 1. Total Sample}

\begin{tabular}{|c|c|c|c|}
\hline \multicolumn{4}{|c|}{ Dependent Variable: g GDP_h } \\
\hline \multicolumn{4}{|c|}{ Method: Pooled Least Squares } \\
\hline \multicolumn{4}{|c|}{ Sample: 19902014} \\
\hline \multicolumn{4}{|c|}{ Included observations: 25} \\
\hline \multicolumn{4}{|c|}{ Cross-sections included: 13} \\
\hline \multicolumn{4}{|c|}{ Total pool (unbalanced) observations: 284} \\
\hline Variable & Coefficient & t-Statistic & Prob. \\
\hline $\mathrm{C}$ & 2.494134 & 0.441895 & 0.6589 \\
\hline LOG(GDP_init) & -0.005460 & -0.088944 & 0.9292 \\
\hline LOG(SEC_edu) & -0.584164 & -0.215158 & 0.8298 \\
\hline GFCF_GDP & 0.053408 & 1.432025 & 0.1533 \\
\hline CONS_f & -0.004271 & -0.489193 & 0.6251 \\
\hline g POP & -1.070130 & -11.12387 & 0.0000 \\
\hline FDI_GDP & 0.112317 & 2.221260 & 0.0272 \\
\hline EXP_GDP & 0.016594 & 1.444446 & 0.1498 \\
\hline g EXP & 0.163231 & 6.195294 & 0.0000 \\
\hline Indivers & 0.693404 & 0.577156 & 0.5643 \\
\hline R-squared & 0.399952 & & \\
\hline Adjusted R-squared & 0.380242 & & \\
\hline F-statistic & 20.29221 & & \\
\hline Prob(F-statistic) & 0.000000 & & \\
\hline
\end{tabular}

Table 2. Total Sample

\begin{tabular}{lccc}
\hline Dependent Variable: g GDP_h & & \\
Method: Pooled EGLS (Cross-section weights) & \\
Sample: 1990 2014 & & \\
Included observations: 25 & & \\
Cross-sections included: 13 & & \\
Total pool (unbalanced) observations: 284 & & Prob. \\
\hline Variable & Coefficient & t-Statistic & 0.5447 \\
C & 2.837235 & 0.606451 & 0.6977 \\
LOG(GDP_init) & 0.020805 & 0.388895 & 0.7511 \\
LOG(SEC_edu) & -0.748856 & -0.317562 & 0.1966 \\
GFCF_GDP & 0.045974 & 1.294377 & 0.2309 \\
CONS_f & -0.007663 & -1.200643 & 0.0000 \\
g POP & -1.088317 & -13.53842 & 0.0046 \\
FDI_GDP & 0.124748 & 2.857838 & 0.0624 \\
EXP_GDP & 0.017680 & 1.871255 & 0.0000 \\
g EXP & 0.132642 & 6.172306 & \\
Indivers & -0.123116 & -0.122429 & 0.9026 \\
\hline R-squared & 0.478654 & & \\
Adjusted R-squared & 0.461530 & & \\
F-statistic & 27.95142 & & \\
Prob(F-statistic) & 0.000000 & & \\
\hline & & & \\
\hline
\end{tabular}

Table 3. Total Sample

Dependent Variable: g GDP_h

Method: Pooled Least Squares

Sample: 19902014

Included observations: 25

Cross-sections included: 13

Total pool (unbalanced) observations: 288

\begin{tabular}{lccc}
\hline Variable & Coefficient & t-Statistic & Prob. \\
C & 0.331090 & 0.055490 & 0.9558 \\
LOG(GDP_init) & 0.042654 & 0.662171 & 0.5084 \\
LOG(SEC_edu) & 0.810356 & 0.282938 & 0.7774 \\
GFCF_GDP & 0.036604 & 0.935030 & 0.3506 \\
CONS_f & -0.005343 & -0.576978 & 0.5644 \\
g POP & -1.043249 & -10.25388 & 0.0000 \\
FDI_GDP & 0.150416 & 2.815447 & 0.0052 \\
EXP_GDP & 0.015685 & 1.283206 & 0.2005 \\
Indivers & -0.576385 & -0.459381 & 0.6463 \\
\hline R-squared & 0.317586 & & \\
Adjusted R-squared & 0.298019 & & \\
F-statistic & 16.23038 & & \\
Prob(F-statistic) & 0.000000 & & \\
\hline
\end{tabular}

Table 4. Total Sample

\begin{tabular}{|c|c|c|c|}
\hline \multicolumn{4}{|c|}{ Dependent Variable: g GDP_h } \\
\hline \multicolumn{4}{|c|}{ Method: Pooled EGLS (Cross-section weights) } \\
\hline \multicolumn{4}{|c|}{ Sample: 19902014} \\
\hline \multicolumn{4}{|c|}{ Included observations: 25} \\
\hline \multicolumn{4}{|c|}{ Cross-sections included: 13} \\
\hline \multicolumn{4}{|c|}{ Total pool (unbalanced) observations: 288} \\
\hline Variable & Coefficient & t-Statistic & Prob. \\
\hline $\mathrm{C}$ & 1.144743 & 0.230016 & 0.8182 \\
\hline LOG(GDP_init) & 0.078472 & 1.369609 & 0.1719 \\
\hline LOG(SEC_edu) & -0.168204 & -0.067133 & 0.9465 \\
\hline GFCF_GDP & 0.062516 & 1.752518 & 0.0808 \\
\hline CONS_f & -0.010278 & -1.681855 & 0.0937 \\
\hline g POP & -1.081946 & -11.61905 & 0.0000 \\
\hline FDI_GDP & 0.175495 & 3.995637 & 0.0001 \\
\hline EXP_GDP & 0.018946 & 1.813529 & 0.0708 \\
\hline Indivers & -1.644207 & -1.560903 & 0.1197 \\
\hline R-squared & 0.371455 & & \\
\hline Adjusted R-squared & 0.353432 & & \\
\hline F-statistic & 20.61027 & & \\
\hline Prob(F-statistic) & 0.000000 & & \\
\hline
\end{tabular}


In the second step we estimated the equation without the growth rate of exports. The results in Table 3 and Table 4 shows an improvement in the results for the control variables mainly for the internal factors of growth investment apprehended by the GFCF and the final consumption, the coefficients are significant for the PEGLS estimate. For the opening variables, it is noted that the relative effect on diversification and the ratio of export to GDP remains non-significant and that the effect has become more important for FDI.

For the third step we estimated the equation without the ratio of exports to GDP. The results do not show an improvement for the control variables.

To summarize the estimate using the total sample, the most plausible results are shown in Table 3 and Table 4. This implies that for all MENA countries, the effect of trade openness on economic growth is a size effect that passes through FDI flows and the weight of exports.

This is yet to be confirmed and raises several questions, especially in the case of non-oil exporting countries. In order to look for some answers, we reiterate the exercise for potential oil exporting countries and non-oil exporting countries.

Table 5. Exporters Potential oil

\begin{tabular}{|c|c|c|c|}
\hline \multicolumn{4}{|c|}{$\begin{array}{l}\text { Dependent Variable: g GDP_h } \\
\text { Method: Pooled Least Squares } \\
\text { Sample: } 19902014 \\
\text { Included observations: } 25 \\
\text { Cross-sections included: } 8 \\
\text { Total pool (unbalanced) observations: } 170\end{array}$} \\
\hline Variable & Coefficient & t-Statistic & Prob. \\
\hline $\mathrm{C}$ & 1.007621 & 0.137513 & 0.8908 \\
\hline LOG(GDP_init) & -0.000848 & -0.013268 & 0.9894 \\
\hline LOG(SEC_edu) & 0.551961 & 0.149943 & 0.8810 \\
\hline GFCF_GDP & 0.026389 & 0.627550 & 0.5312 \\
\hline CONS_f & -0.014785 & -1.084555 & 0.2798 \\
\hline g POP & -1.078345 & -9.840744 & 0.0000 \\
\hline FDI_GDP & 0.079313 & 1.189093 & 0.2362 \\
\hline EXP_GDP & 0.023519 & 1.670967 & 0.0967 \\
\hline g EXP & 0.164959 & 5.020989 & 0.0000 \\
\hline Indivers & 1.013272 & 0.625255 & 0.5327 \\
\hline R-squared & 0.473631 & & \\
\hline Adjusted R-squared & 0.444023 & & \\
\hline F-statistic & 15.99661 & & \\
\hline Prob(F-statistic) & 0.000000 & & \\
\hline
\end{tabular}

Table 6. Exporters Potential oil

Dependent Variable: g GDP_h

Method: Pooled EGLS (Cross-section weights)

Sample: 19902014

Included observations: 25

Cross-sections included: 8

Total pool (unbalanced) observations: 170

\begin{tabular}{lccc}
\hline Variable & Coefficient & t-Statistic & Prob. \\
C & 2.558364 & 0.392788 & 0.6950 \\
LOG(GDP_init) & 0.003373 & 0.060168 & 0.9521 \\
LOG(SEC_edu) & -0.053513 & -0.015515 & 0.9876 \\
GFCF_GDP & -0.003897 & -0.088230 & 0.9298 \\
CONS_f & -0.017581 & -1.499116 & 0.1358 \\
g POP & -1.032213 & -10.09970 & 0.0000 \\
FDI_GDP & 0.113267 & 1.756705 & 0.0809 \\
EXP_GDP & 0.022666 & 1.816823 & 0.0711 \\
g EXP & 0.128501 & 4.965709 & 0.0000 \\
Indivers & 1.325649 & 0.854511 & 0.3941 \\
\hline R-squared & 0.521621 & & \\
Adjusted R-squared & 0.494712 & & \\
F-statistic & 19.38477 & & \\
Prob(F-statistic) & 0.000000 & & \\
\hline
\end{tabular}

Beginning with the subsample of potential oil exporting countries, the results are presented in Table 5 and Table 6. We noted that the effect of export growth and the FDI effect are significant in all cases. However, for export diversification the results show that it has no effect on growth. Results on control variables show that internal growth factors do not work well.

For model estimation for sub-sample of non-oil exporting countries the results are presented in Table 7 and Table 8 . The results show that the coefficient associated with the export growth rate variable is statistically significant in all cases, however the ratio of exports to GDP is non-robust. This implies for the case of non-oil exporting MENA countries the growth rate of exports is the main mechanism of the effect of trade openness on economic growth. Furthermore, for FDI, the results show that they do not have a significant effect. We consider the PEGLS estimate to be the best. The results also emphasized the importance of internal growth factors. Indeed, the coefficients relating to final consumption and investment are significant.

Table 7. No Potential Petroleum Exporters

\begin{tabular}{|c|c|c|c|}
\hline \multicolumn{4}{|c|}{ Dependent Variable: g GDP_h } \\
\hline \multicolumn{4}{|c|}{ Method: Pooled Least Squares } \\
\hline \multicolumn{4}{|c|}{ Included observations: 25} \\
\hline \multicolumn{4}{|c|}{ Cross-sections included: 5} \\
\hline \multicolumn{4}{|c|}{ Total pool (unbalanced) observations: 114} \\
\hline Variable & Coefficient & t-Statistic & Prob. \\
\hline $\mathrm{C}$ & -25.97800 & -1.364999 & 0.1752 \\
\hline LOG(GDP_init) & 0.376056 & 1.120954 & 0.2649 \\
\hline CONS_f & 0.096423 & 1.590115 & 0.1148 \\
\hline LOG(SEC_edu) & 1.043291 & 0.195340 & 0.8455 \\
\hline GFCF_GDP & 0.270393 & 2.447120 & 0.0161 \\
\hline FDI_GDP & 0.109381 & 1.038314 & 0.3015 \\
\hline g POP & -1.139400 & -3.669441 & 0.0004 \\
\hline g EXP & 0.163043 & 3.583989 & 0.0005 \\
\hline Indivers & 13.13791 & 1.185572 & 0.2385 \\
\hline R-squared & 0.287016 & & \\
\hline Adjusted R-squared & 0.232694 & & \\
\hline F-statistic & 5.283556 & & \\
\hline Prob(F-statistic) & 0.000014 & & \\
\hline
\end{tabular}

Table 8. No Potential Petroleum Exporters

\begin{tabular}{|c|c|c|c|}
\hline \multicolumn{4}{|c|}{ Dependent Variable: g GDP_h } \\
\hline \multicolumn{4}{|c|}{ Method: Pooled EGLS (Cross-section weights) } \\
\hline \multicolumn{4}{|c|}{ Included observations: 25} \\
\hline \multicolumn{4}{|c|}{ Cross-sections included: 5} \\
\hline \multicolumn{4}{|c|}{ Total pool (unbalanced) observations: 114} \\
\hline Variable & Coefficient & t-Statistic & Prob. \\
\hline $\mathrm{C}$ & -23.52843 & -1.189900 & 0.2368 \\
\hline LOG(GDP_init) & 0.317006 & 0.877668 & 0.3821 \\
\hline CONS_f & 0.090529 & 1.746143 & 0.0837 \\
\hline LOG(SEC_edu) & 0.891396 & 0.165238 & 0.8691 \\
\hline GFCF_GDP & 0.312831 & 3.120491 & 0.0023 \\
\hline FDI_GDP & 0.119301 & 1.318954 & 0.1901 \\
\hline g POP & -1.400621 & -6.583159 & 0.0000 \\
\hline g EXP & 0.168390 & 4.295458 & 0.0000 \\
\hline Indivers & 9.787905 & 1.127621 & 0.2621 \\
\hline R-squared & 0.492910 & & \\
\hline Adjusted R-squared & 0.454274 & & \\
\hline F-statistic & 12.75797 & & \\
\hline Prob(F-statistic) & 0.000000 & & \\
\hline
\end{tabular}




\section{Conclusion}

The conclusion that can be drawn from this work is that openness to international trade is generally beneficial for the countries of the MENA region, with degrees varying according to the structure of trade and the nature of the goods to be exchanged and according to whether the country Belongs or not to the group of net oil exporters. Indeed, for the country non-oil exporters growth is based on internal factors, investment and final consumption. The effect of openness is also important and that is going through the growth of exports. According to the results, for these countries the diversification of exports is very important insofar as, in addition to its significant effect on economic growth, it is a major asset in supporting exports. Regarding the role of FDI, it is marginal and not significant. This result is due to the nature of institutional factors relating to governance and the nature of these investment flows, which are essentially constituted by the subcontracting of certain textile and services activities with low content Technological development, against the conditions necessary for FDI to be beneficial. However, it is pointed out that the low the effect is manifested through consumption insofar as foreign investment flows strongly contribute to job creation.

For potential oil exporting countries the results are different, internal growth factors do not work well. The contributions of final consumption and investment to growth are low, this result can be explained by the fact that the consumption of these countries consists mainly of imported finished products. However, the positive effect of international integration is mainly due to the export of oil, as evidenced by the small diversification that characterizes the exports of these countries. For FDI, the effect is positive and significant because these countries are potential investors on a global scale.

The recommendations that can be drawn from this work can be summarized as follows: Non-oil-exporting MENA countries are called upon to rely more on diversification to support and strengthen the pace of exports, which is a very important factor in taking advantage of The opening of trade. Strengthen the role of institutions and improve the attractiveness of high-tech FDI. Oil-exporting are also called upon to diversify their economies and boost the internal drivers of economic growth.

Finally, it is necessary to point out certain shortcomings of this paper which can be the object of future research and which are not to integrate variables relating to institutional factors, financial factors as well as exchange rate effects.

\section{References}

[1] Lee K. \& Kim, B.Y. (2009). "Both Institutions and Policies Matter but Differently for Different Income Groups of Countries: Determinants of Long-Run Economic Growth Revisited”, World Development, 37 (3), 533-549.

[2] Rodrik D., Subramanian A. and Trebbi F. (2004). "Institutions rule: The primacy of institutions over geography and integration in economic development”, Journal of Economic Growth, 9, 131-165.

[3] Jones B.J. and Olken B.A. (2005). "Do Leaders Matter? National leadership and Growth since World War II”, The Quarterly Journal of Economics, 835-864.
[4] Hausmann R., Pritchett L. and Rodrik D. (2005). "Growth accelerations”, Journal of Economic Growth, 10, 303-329.

[5] Rodrik D. (2006). "Goodbye Washington consensus hello Washington confusion?”, Journal of Economic Literature, 44 (4), 973-987.

[6] Eichengreen B., Park, D. and Shin, K. (2012). "When Fast Growing Economies Slow Down: International Evidence and Implications for China”, Asian Economic Papers, 11, $42-87$.

[7] Lee K. (2013). "Schumpeterian Analysis of Economic Catch-up: Knowledge, Path-Creation, and the Middle-Income Trap”, Cambridge University Press, United Kingdom.

[8] World Bank, (2010). "Escaping the Middle-income trap, World Bank East Asia and Pacific Economic Update: Robust Recovery, Rising Risks”, Washington DC: World Bank, 2, 27-43.

[9] Rodriguez, F. and Rodrik, D. (2001). "Trade Policy and Economic Growth: A Skeptic's Guide to the Cross-National Evidence”, in B. Bernanke and K. Rogoff (eds), NBER Macroeconomics Annual 2000, Cambridge, MA: MIT Press, 0-262-02503-5, 15, 261-338.

[10] Yanikkaya, H. (2003). "Trade openness and economic growth: a cross-country Empirical Investigation”, Journal of development Economics, 72 (1), 57-89.

[11] Vamvakidis A. (2002). "How robust is the Growth-Openness Connection? Historical Evidence”, Journal of Economic growth, 7 (1), 57-80.

[12] Brenton P. Saborowski C. and Uexkull E. (2010). "What Explains the Low Survival Rate of Developing Country Export Flows?”, The World Bank Economic Review, 24 (3), 474-499.

[13] Nitsch V. (2009). "Die Another Day: Duration in German Import Trade.”, Review of World Economics, 145, 133-154.

[14] Fugazza, M. and Molina, A.C. (2009). "The Determinants of Trade Survival.”, HEI Working Papers No. 5.

[15] Cadot O., Carrère C. and Strauss-Kahn V. (2011). "Export Diversification: What's behind the Hump?", Review of Economics and Statistics, 93, 590-605.

[16] Cadot O., Carrère C. and Strauss-Khan V. (2013). "Trade Diversification, Income and Growth: What Do We Know?", Journal of Economic Surveys, 27 (4), 790-812.

[17] Helpman E. and Krugman P. K. (1985). "Market Structure and Foreign Trade", Cambridge, Massachusetts Institute of Technology (MIT) Press.

[18] Krugman P. K. (1991). “Increasing Returns and Economic Geography”, Journal of Political Economy, 99 (3), 483-499.

[19] Fontagné L. Mayer T. and Zignano S. (2005). "Trade in the Triad : How easy in the access to large markets", Canadian Journal of Economics, 38, 1401-1430.

[20] Tinbergen J. (1962). "Shaping the World Economy, The Twentieth Century Fund”, New York.

[21] Disdier A. C. et Head K. (2008). "The puzzling persistence of the distance effect on bilateral trade", Review of Economics and Statistics, 90, 37-48.

[22] Young A. (1991). "Leaning by doing and the dynamic effects of international trade”, Quarterly Journal of Economics, 106 (2), 369-405.

[23] Grossman G. M. and Helpman E. (1991). "Quality ladders in the theory of growth”, Review of Economic Studies, 58, 43-61.

[24] Rivera-Batiz L. A. and Romer P. M. (1991). "Economic Integration and Endogenous Growth", The Quarterly Journal of Economics, 106 (2), 531-555.

[25] Mankiw N. G., Romer D. and Weil D. N. (1992). “A Contribution to the Empirics of Economic Growth.”, Quarterly Journal of Economics, 107 (2), 407-437, Massachusetts Institute of Technology Press, 10.2307/2118477.

[26] Solow R. M. (1956). "A Contribution to the Theory of Economic Growth.”, Quarterly Journal of Economics, 70, 65-94.

[27] Rutherford T. F. et Tarr D. G. (1998). "Trade liberalization and Endogenous Growth in a Small Open Economy”, Policy Research Working Paper, N¹970, The World Bank.

[28] Se-Jik Kim et Young Jin Kim (1999). "Growth gains from trade and education”, IMF Working Paper, WP/99/33.

[29] Sachs J. and Warner A. (1995). "Economic Reform and the Process of Global Integration”, Brookings Paper on Economic Activity, 26 (1), 1-117.

[30] Vamvakidis A. (1999). "Regional trade agreements or broad liberalization: which path leads to faster growth?”, IMF Staff Papers, 46, 42-68. 
[31] Harrison A. (1996). "Openness and Growth: A Time-Series, Cross-Country Analysis for Developing Countries”, Journal of Development Economics, 48 (2), 419-447.

[32] Borensztein E., De Gregorio J. and Lee J-W. (1998). "How does foreign direct investment affect economic growth?”, Journal of International Economics, 45, 115-135.

[33] Hsiao C. and Shen Y. (2003). "Foreign Direct Investment and Economic Growth: The Importance of Institutions and Urbanization.”, Economic Development and Cultural Change, 51 (4), 883-896.

[34] Adams S. (2009). "Foreign Direct Investment, Domestic Investment, and Economic Growth in Sub-Saharan Africa.”, Journal of Policy Modeling, 31 (6), 939-949.

[35] Agosin M. R., Alvarez R. and Bravo-Ortega C. (2011). "Determinants of Export Diversification Around the World: 19622000”, The World Economy, 35 (3), 295-315.

[36] Agosin M. R. (2008). "Export Diversification and Growth in Emerging Economies.”, CEPAL Review, 97, 115-131.

[37] Al-Marhubi F. (2000). "Export Diversification and Growth: An Empirical Investigation.”, Applied Economics Letters, 7 (9), 559562.

[38] Ferranti D., Perry G. E. Lederman D. and Maloney W. F. (2002) "From Natural Resources to the Knowledge Economy", The World Bank, Washington, DC.

[39] Pineres S. A. G. and Ferrantino, M. (1997). "Export diversification and structural dynamics in the growth process: the case of Chile”, Journal of Development Economics, 52, 35- 91.

[40] Felipe J., Arnelyn A. and Utsav K. (2012). "Tracking the Middleincome Trap: What Is It, Who Is in It, and Why? ”, Levy Economics Institute Working Paper no. 715.

[41] Balaguer J. and Cantavella-Jorda M. (2004). "Structural Change in Exports and Economic Growth: Cointegration and Causality Analysis for Spain (1961-2000).” Applied Economics, 36, 473-477.

[42] Worz, J. (2005). "Dynamics of Trade specialization in developed and less developed countries”, Emerging Markets Finance and Trade, 41 (3), 92-111.

[43] Eaton J., Eslava M., Kugler M., and Tybout J. (2008). "Export Dynamics in Colombia: Transaction Level Evidence." In The Organization of Firms in a Global Economy, edited by E. Helpman, D. Marin and T. Verdier, 231-272. Cambridge, MA: Harvard University Press.

[44] Besedes T. and Prusa T. (2007). "The Role of Extensive and Intensive Margins and Export Growth”, NBER Working Paper 13628.

[45] Brenton P., and Newfarmer R. (2007). "Watching More Than the Discovery Channel: Export Cycles and Diversification in Development.”, Policy Research Working Paper, 4302, World Bank, Washington DC.

[46] Helpman E., Melitz M. J. and Rubinstein Y. (2008). "Estimating Trade Flows: Trading Partners and Trading Volumes.”, The Quarterly Journal of Economics, 123 (2), 441-487.

[47] Reinhardt N. (2000). "Back to Basics in Malaysia and Thailand: The Role of Resource-Based Exports in Their Export-Led Growth”, World Development, 28 (1), Elsevier Science Ltd, 57-77.

[48] Jung M. and Lee K. (2010). "Sectoral systems of innovation and productivity catch-up: determinants of the productivity gap between Korean and Japanese firms", Industrial and Corporate Change, 19 (4), 1037-1069.

[49] Rebelo S. (1991). "Long-Run Policy Analysis and Long-Run Growth.”, Journal of Political Economy, 99, 500-521.

[50] Barro R. (1991). "Economic Growth in a Cross-section of Countries”, Quarterly Journal of Economics, 106 (2), 407-443.

[51] Barro, R. J., and Sala-i-Martin X. (1992) "Convergence”, Journal of Political Economy, 100 (2), 223-251.

[52] Alfaro L., Chanda A., Kalemli-Ozcan S. and Sayek S. (2004) "FDI and Economic Growth: The Role of Local Financial Markets.”, Journal of International Economics, 64 (1), 89-112.

[53] Amurgo-Pacheco A. and Pierola M. D. (2008). "Patterns of Export Diversification in Developing Countries: Intensive and
Extensive Margins.”, Policy Research Working Paper WPS4473, Washington DC, World Bank.

[54] Arellano M. and Bover O. (1995). “Another Look at Instrumental Variable Estimation of Error Component Models.”, Journal of Econometrics, 68, 29-51.

[55] Arthur Lewis W. (1980). "The Slowing Down of the Engine of Growth.”, The American Economic Review, 70 (4), 555-564.

[56] Ben-David D. and Loewy M. (1998). "Free Trade, Growth and Convergence”, Journal of Economic Growth, 3,143-170.

[57] Ben-David D. and Loewy M. (2000) "Knowledge Dissemination, Capital Accumulation, Trade and Endogenous Growth”, Oxford Economic Papers, 52, 637-650.

[58] Ben-David D. and Loewy M. (2003). “Trade and the Neoclassical Growth Model”, Journal of Economic Integration, 18, 1-16.

[59] Chang R., Kaltani L. and Loayza N. V. (2009). "Openness Can Be Good for Growth: The Role of Policy Complementarities”, Journal of Development Economics, 90, 33-49.

[60] Edwards S. (1998). “Openness, Trade Liberalization, and Growth in Developing Countries”, Journal of Economic Literature, 31 (3), 1358-1393.

[61] Falk M. (2009). "High-tech Exports and Economic Growth in Industrialized Countries.”, Applied Economics Letters, 16 (10), 1025-1028.

[62] Frankel J. A. and Romer D. (1999). “Does Trade Cause Growth?”, American Economic Review, 80, 379-399.

[63] Gnangnon S. K. (2017). "Multilateral Trade Liberalization and Foreign Direct Investment Inflows”, Economic Affairs, 37 (1), 66-84.

[64] Grossman G. M. and E. Helpman (1990). "Comparative Advantage and Long-Run Growth”, American Economic Review, 80, 796-815.

[65] Hasse H. (2009). "Export Diversification and Economic Growth.”, In Breaking into New Market, 55-80, World Bank.

[66] Hausman R., Hwank J. and Rodrik D. (2007). "What You Export Matters.”, Journal of Economic Growth, 12, 1-25.

[67] Henrekson M., Torestensson J. and Torestensson R. (1997). "Growth effects of European integration", European Economic Review, 41, 1537-1557.

[68] Hesse H. (2006). "Export Diversification and Economic Growth.”, Washington DC, World Bank.

[69] Kim Y. K., Lee K., Park W. G. and Choo K. (2012). “Appropriate Intellectual Property Protection and Economic Growth in Countries at Different Levels of Development.”, Research Policy, 41 (2), 358-375.

[70] Lee K., and Mathews J. (2012). "Firms in Korea and Taiwan: Upgrading in the Same Industry and Entries into New Industries for Sustained Catch-up.”, In The Innovative Firms in the Emerging Market Economies, edited by J. Cantwell and E. Amann. Oxford: Oxford University Press.

[71] Lee K. and Temesgen T. (2009). "What Makes Firms Grow in Developing Countries: An Extension of the Resource-Based Theory of the Firm Growth and Empirical Analysis.”, International Journal of Technological Learning, Innovation and Development, 1 (3), 139-172.

[72] Lee K., Kim B.Y., Park Y. Y., and Sanidas E. (2013). "Big Businesses and Economic Growth: Identifying a Binding Constraint for Growth with Country Panel Analysis.”, Journal of Comparative Economics, 41 (2), 561-582.

[73] Ramanayake S. S. and Lee K. (2015). “Does openness lead to sustained economic growth? Export growth versus other variables as determinants of economic growth", Journal of the Asia Pacific Economy, 20 (3), 345-368.

[74] Ratnaike Y. C. (2012). "Is There an Empirical Link Between Trade Liberalization and Export Performance? ”, Economics Letters, 117, 375-378.

[75] Wacziarg, R. (2001). "Measuring the Dynamic Gains from Trade", World Bank Economic Review, 15, 393-429.

[76] World Bank (2016). "World Development Indicators Online”, Washington DC, World Bank. 